\title{
LETTER
}

\section{Response to 'Ramipril attenuates lipid peroxidation and cardiac fibrosis in an experimental model of rheumatoid arthritis'}

\author{
Di Wang, Shanshan Hu and Wei Wei* \\ See related research by Shi et al., http://arthritis-research.com/content/14/5/R223, and related letter by Shi et al., \\ http://arthritis-research.com/content/15/2/406
}

We read with great interest the recent issue of Arthritis Research \& Therapy in which Shi and colleagues [1] investigated the effects of ramipril on oxidative stress and fibrosis in the heart of rats with adjuvant arthritis. The authors concluded that ramipril reversed arthritis scoring and decreased markers of oxidative stress, inflammation, and tissue fibrosis. Undoubtedly, their findings will promote the attempt to diminish the cardiovascular risk of patients with rheumatoid arthritis (RA) by using angiotensin-converting enzyme inhibitors (ACEIs) or angiotensin receptor blockers (ARBs) or both.

However, several important aspects should be considered in the interpretation of this study. As described by the authors, adjuvant arthritis was induced successfully in female rats with a $100 \%$ incidence rate, but actually the male rats were used in most cases [2-4]. Therefore, we speculate that this discrepancy may be related to the impact of arthritis on cardiac fibrosis and oxidative stress status in the heart of rats with adjuvant arthritis. In addition, the dosage of ramipril is a matter of debate. In a randomized and double-blind clinical study, treatment with $10 \mathrm{mg} /$ day ramipril effectively improved endothelial function in patients with RA [5]. Intriguingly, how was the ramipril dosage $(10 \mathrm{mg} / \mathrm{kg}$ per day) used in this animal study calculated?

Unlike previous reports focusing on the effect of ramipril and ARBs on vascular function with RA and experimental models [2,5], the article by Shi and colleagues reported that ramipril improved cardiac function in rats with adjuvant arthritis. Although we list some methodological issues here, we believe that the authors' findings strongly suggest a promising therapeutic role of ACEIs and ARBs on both cardiovascular risk and arthritis in patients with RA.

\section{Abbreviations \\ ACEl, angiotensin-converting enzyme inhibitor; ARB, angiotensin receptor blocker; RA, rheumatoid arthritis.}

\section{Competing interests}

The authors declare that they have no competing interests.

Published: 3 April 2013

\section{References}

1. Shi Q, Abusarah J, Baroudi G, Fernandes JC, Fahmi H, Benderdour M: Ramipril attenuates lipid peroxidation and cardiac fibrosis in an experimental model of rheumatoid arthritis. Arthritis Res Ther 2012, 14:R223.

2. Sakuta T, Morita Y, Satoh M, Fox DA, Kashihara N: Involvement of the reninangiotensin system in the development of vascular damage in a rat model of arthritis: effect of angiotensin receptor blockers. Arthritis Rheum 2010, 62:1319-1328.

3. Price A, Lockhart JC, Ferrell WR, Gsell W, McLean S, Sturrock RD: Angiotensin II type 1 receptor as a novel therapeutic target in rheumatoid arthritis: in vivo analyses in rodent models of arthritis and ex vivo analyses in human inflammatory synovitis. Arthritis Rheum 2007, 56:441-447.

4. Dalbeth N, Edwards J, Fairchild S, Callan M, Hall FC: The non-thiol angiotensin-converting enzyme inhibitor quinapril suppresses inflammatory arthritis. Rheumatology (Oxford) 2005, 44:24-31.

5. Flammer AJ, Sudano I, Hermann F, Gay S, Forster A, Neidhart M, Künzler P, Enseleit F, Périat D, Hermann M, Nussberger J, Luscher TF, Corti R, Noll G, Ruschitzka F: Angiotensin-converting enzyme inhibition improves vascular function in rheumatoid arthritis. Circulation 2008, 117:2262-2269.

doi:10.1186/ar4195

Cite this article as: Wang D, et al.: Response to 'Ramipril attenuates lipid peroxidation and cardiac fibrosis in an experimental model of rheumatoid arthritis'. Arthritis Research \& Therapy 2013, 15:405.

\footnotetext{
*Correspondence: wwei@ahmu.edu.cn

Institute of Clinical Pharmacology, Anhui Medical University, Key Laboratory of Anti-inflammatory and Immunopharmacology of China Education Ministry, Hefei 230032, Anhui Province, PR China
} 